\title{
PREFERENTIAL TRADE AGREEMENTS AND TAX COMPETITION FOR FOREIGN DIRECT INVESTMENT
}

\author{
HORST RAFF
}

CESIFO WORKING PAPER No. 763

CATEgory 1: Public FinANCE

August 2002

\footnotetext{
An electronic version of the paper may be downloaded

- from the SSRN website: www.SSRN.com

- from the CESifo website: www.CESifo.de
} 


\title{
PREFERENTIAL TRADE AgREEMENTS AND TAX COMPETITION FOR FOREIGN DIRECT INVESTMENT
}

\begin{abstract}
This paper examines how free-trade agreements and customs unions affect the location of foreign direct investment (FDI) and social welfare, taking into account that governments may adjust taxes and external tariffs to compete for FDI. Conditions are identified under which a free-trade agreement leads to FDI and under which this improves welfare. The welfare effect is shown to depend on the relative size of efficiency gains in production and government revenue losses due to tax competition. A free-trade agreement may fail to induce welfare-improving FDI, creating a role for a customs union.
\end{abstract}

JEL Classification: H25, F13, F23.

Keywords: preferential trade agreements, tax competition, multinational enterprises.

\author{
Horst Raff \\ Department of Economics \\ University of Kiel \\ Wilhelm-Seelig-Platz 1 \\ 24098 Kiel \\ Germany \\ raff@econ-theory.uni-kiel.de
}

I would like to thank seminar participants at the IMF and the Universities of Kiel, Munich and Cologne for helpful comments and suggestions. 


\section{Introduction}

This paper examines the effect of preferential trade agreements on the location of foreign direct investment (FDI) and social welfare, taking into account that governments may adjust their tax policy to compete for FDI. There is considerable empirical evidence that preferential trade agreements, such as free-trade areas (FTAs) and customs unions (CUs), affect FDI flows. For instance, the creation of the European customs union in 1968 and especially the Single European Act of 1986/87 were associated with significant inflows of U.S. and Japanese FDI [see, for instance, Motta and Norman (1996) and Pain (1997)]. Inflows were particularly strong in relatively low-cost locations such as Ireland. Similar effects were observed in the case of the North American Free Trade Agreement (NAFTA), which particularly boosted FDI into Mexico. Some authors, including Ethier (1998), have argued that attracting FDI was in fact one of the main reasons why some countries have pursued such agreements. Many preferential trade agreements, including NAFTA, explicitly stipulate the removal of FDI review procedures and other barriers to direct investment. Another possible effect is that the removal of internal trade barriers may allow companies to rationalize and concentrate production in low-cost locations within the preferential trade area. This was pointed out, for instance, by Emerson et al. (1988), the Royal Commission (1985) and Pain (1997). Empirical evidence of this effect for NAFTA is found by Niosi (1994).

Given the potential of preferential trade agreements to affect the location choices of foreign investors, governments may find it tempting to intervene to try to attract new firms or to prevent existing firms from leaving. Competition for FDI especially on an intra-regional basis is well documented, and there is some evidence that it has increased in line with regional integration [Bond and Guisinger (1985)]. To a significant extent this competition is incentive-based. ${ }^{1}$ According to UNCTAD [(1996), Table III.1], the use of fiscal incentives to attract FDI — such as tax holidays, reductions in the standard corporate income tax rate, etc. - has increased in Europe between the mid-1980s and early 1990s. ${ }^{2}$ The study reports a similar

\footnotetext{
${ }^{1}$ There may also be an effect on corporate taxes. For example, Benassy-Quere et al. (2000) find that in the process of European integration nominal and effective corporate tax rates in the EU have decreased.

${ }^{2}$ Of the 20 European countries surveyed, 16 provided reductions of standard income-tax rates, 7 provided tax holidays, 10 offered accelerated depreciation, 5 gave investment and reinvestment allowances, 5 offered deductions from social security contributions, 9 granted specific deductions on gross earnings for income tax purposes or reductions in other taxes, 7 provided exemptions from import duties and 6 offered duty drawbacks. The only instrument that appears to have been used less was accelerated depreciation.
} 
trend in the United States and Canada. The main objectives pursued with these incentives appear to have changed as well during this period. UNCTAD [(1996), Table III.4] argues that in the EU as well as in the United States and Canada more incentives were given to stimulate FDI and exports and fewer were given for sectoral development and restructuring, priority industries, and research and development.

Examples of incentive-based competition in Europe are listed in Table 1. These examples suggest that multinational firms, after identifying possible locations for a project, shop around for the most attractive combination of location-specific fundamentals and incentives [see also Oman (2000)]. In the UNCTAD survey, Samsung offered as key factors influencing its decision to invest in England (i) access to the European single market; (ii) high labor productivity and competitive wage rates; (iii) an attractive incentive package; and (iv) good transport infrastructure to markets. Mercedes-Benz and Swatch gave almost exactly the same reasons for their choice of locating in France, as did Ford and Volkswagen for their decision to locate in Spain. The desire to supply the European market from a single low-cost location within the EU providing significant incentives also appears in many of the other examples listed in the UNCTAD survey [UNCTAD (1996), Boxes III.4 to III.5].

Many observers have noted that competition for FDI may resemble a prisoner's dilemma with countries setting taxes too low or offering excessive incentives [see Hines (1997), Wilson (1999) and Gordon and Hines (2002) for surveys]. Recently both the EU and the OECD have developed standards for good behavior in international taxation that would require the removal of tax incentives for FDI [see Keen (1999) for a discussion]. Nevertheless, preferential trade agreements typically only restrict the use of (some) trade policy instruments, but do not specify how the signatories are to choose other instruments, such as corporate taxes, investment subsidies and, in the case of an FTA, tariffs against third countries. This raises several interesting questions. For instance, how will a preferential trade agreement affect the member countries' taxes/subsidies on FDI and tariffs against nonmembers? How will it affect location choices? Will potential efficiency gains from free trade be offset by inefficiently high FDI incentives? Are there any differences between FTAs and CUs in this respect, i.e., does the adoption of common external tariffs offer benefits relative to having each member country set its own external tariffs?

The purpose of this paper is to develop a simple model in which some of these questions can be examined. I consider three countries - two of them representing potential members of a FTA or CU, the other 
Table 1: Examples of Foreign Direct Investment and

Financial Incentives in the EU

\begin{tabular}{|c|c|c|c|c|c|c|}
\hline City, Country & Year & Company & $\begin{array}{l}\text { Other Locations } \\
\text { Considered }\end{array}$ & $\begin{array}{l}\text { Total State } \\
\text { Financial } \\
\text { Incentives } \\
\text { (million \$) }\end{array}$ & $\begin{array}{l}\text { Company } \\
\text { Investment } \\
(\text { million } \$)\end{array}$ & $\begin{array}{l}\text { Financal } \\
\text { Ince ntives } \\
\text { per Job }(\$)\end{array}$ \\
\hline $\begin{array}{l}\text { New Castle } \\
\text { upon Tyne, UK }\end{array}$ & 1995 & Siemens & $\begin{array}{l}\text { Austria, Germany, } \\
\text { Ireland, Portugal, } \\
\text { Singapore }\end{array}$ & 76.92 & $1,428.6$ & 51,280 \\
\hline $\begin{array}{l}\text { Hambach, } \\
\text { Lorraine, France }\end{array}$ & 1995 & $\begin{array}{l}\text { Mercedes-Benz, } \\
\text { Swatch }\end{array}$ & $\begin{array}{l}\text { Austria, Belgium, } \\
\text { Czech Republic, } \\
\text { Germany, Italy, } \\
\text { Switzerland }\end{array}$ & 111 & 370 & $\mathrm{n} / \mathrm{a}$ \\
\hline $\begin{array}{l}\text { Castle Bromwich, } \\
\text { Birmingham, } \\
\text { Whitley, UK }\end{array}$ & 1995 & Jaguar & Detroit, USA & 128.72 & 767 & 128,720 \\
\hline $\begin{array}{l}\text { North-East } \\
\text { England }\end{array}$ & $1994 / 95$ & Samsung & $\begin{array}{l}\text { France, Germany, } \\
\text { Portugal, } \\
\text { Spain } \\
\end{array}$ & 89 & 690.3 & 29,675 \\
\hline $\begin{array}{l}\text { Setubal, } \\
\text { Portugal }\end{array}$ & 1991 & $\begin{array}{l}\text { Ford, } \\
\text { Volkswagen }\end{array}$ & UK, Spain & 483.5 & 2,603 & 254,451 \\
\hline
\end{tabular}

Source: data drawn from UNCTAD (1996), Table III.6. 
representing the rest of the world - and a foreign investor with monopoly power who has a choice of locating a plant in one or more of the potential member countries or serving them via exports from an existing plant in the rest of the world. When two countries form a FTA, they eliminate their internal tariffs but continue to choose taxes on the firm's profit and their own tariffs against the third country non-cooperatively. If two countries form a $\mathrm{CU}$, they select a common external tariff and hence compete only in taxes. Thus the closer the integration between the two countries, the more policy instruments they give up.

In this framework, I derive conditions under which a FTA leads to changes in the pattern of FDI and in taxes and external tariffs and identify the associated welfare effects. Among other things, I show that a FTA may induce FDI. Whether this raises or lowers welfare is shown to depend on the relative size of the efficiency gain from integration and the revenue loss associated with tax competition. Under certain conditions a FTA does not lead to FDI, even though FDI would be welfare improving. This may happen, because equilibrium external tariffs are too low in equilibrium to induce FDI, or because there are multiple equilibria and countries are stuck in one that does not support FDI. A CU, by requiring countries to coordinate on a common external tariff, may then induce FDI and raise welfare.

The paper follows in the tradition of the growing literature on FDI and recent papers on tax competition for FDI, which stress the discrete nature of firms and location choices. This literature also views multinational enterprises as possessing firm-specific assets that allow them to penetrate foreign markets but also confer market power [see Markusen (1995) for a survey of the FDI literature]. A number of papers, including Motta and Norman (1993, 1996), Donnenfeld (1998) and Neary (2002), examine how CUs affect FDI decisions in monopoly or oligopoly. However, these papers do not consider how governments may adapt other policy instruments to influence FDI flows. Papers on tax competition for FDI typically examine the effects of removing internal trade barriers, but do not consider how countries would change their external tariffs; hence they also do not distinguish between FTAs and CUs. Haufler and Wooton (1999), for instance, analyze how a reduction in transport costs affects tax competition between two countries for a foreign monopolist. They consider countries of different size, whereas Davies (2001) examines a similar situation allowing for differences in production costs. Barros and Cabral (2000) examine tax competition for a foreign investor, but do not allow for exports. Tax competition between two countries in the case of a duopoly is studied by Janeba (1998); but this paper also does not consider the role of preferential trade agreements. 
The rest of the paper is organized as follows. Section 2 presents the model and Section 3 some preliminary steps. Equilibrium taxes, tariffs and location choices without preferential trade are analyzed in Section 4 . Section 5 examines the effects of preferential trade agreements. Extensions are considered in Section 6, and Section 7 concludes.

\section{The Model}

Consider a world consisting of three countries, labeled $h, l$ and $f$. Countries $h$ and $l$ may form a FTA or $\mathrm{CU}$, country $f$ represents the rest of the world. There is a firm that produces good $X$, is owned by residents of $f$, and operates a production facility in $f$. The firm has to decide how to market its product in $h$ and l. Its options include exporting the good from its plant in $f$, or becoming a multinational by locating a production facility in $h$ and/or $l$.

The representative households in $h$ and $l$ have identical preferences. Each household consumes two goods: good $X$, and a numeraire good $Y$ that is competitively provided in each country. The utility function of a representative household residing in country $i=h, l$ is given by

$$
U_{i}=x_{i}-\frac{1}{2} x_{i}^{2}+y_{i}
$$

where $x_{i}$ and $y_{i}$ denote the consumption of goods $X$ and $Y$, respectively. Denoting the consumer price of good $X$ in country $i$ by $p_{i}$, tax and tariff revenue (which is redistributed by the government in lump-sum fashion) by $R_{i}$, and income from other sources by $M_{i}$, the household's budget constraint is

$$
p_{i} x_{i}+y_{i}=M_{i}+R_{i}
$$

Maximizing utility subject to the budget constraint yields as demand for good $X$ in country $i=h, l$

$$
x_{i}=1-p_{i}
$$

Production in country $i=h, l, f$ involves a constant marginal cost, $c_{i}<1$. This cost may differ across countries due to differences in wages, in the availability of intermediate inputs, etc. We assume that $c_{h}>c_{l}$, making $h$ the high-cost and $l$ the low-cost location in the potential preferential trade area. Operating a plant also involves a fixed cost, which is denoted by $G$. For simplicity I will keep track only of the fixed cost associated with operating a plant in $h$ or $l$. The transport cost between $h$ and $l$ is assumed to be zero; the 
cost of transporting goods produced in $f$ to markets in $h$ and $l$ is included in $c_{f}$. Markets in the different countries are segmented so that the firm can set prices independently in each market. This together with the assumption of constant marginal cost lets us abstract in our analysis from the market in $f$ and the firm's pricing strategy and operating profit there. ${ }^{3}$

The governments of $h$ and $l$ tax profits and imports to maximize the utility of the respective representative agent, or social welfare for short. Hence social welfare equals the sum of tax/tariff revenue and consumer surplus. The government of country $f$, for simplicity, does not levy taxes. ${ }^{4}$ The tax instruments of country $i$ 's $(i=h, l)$ government consist of a profit tax, levied at rate $t_{i}$, that it can collect if the firm establishes a production facility in the country, and specific tariffs, $r_{i j}$, on imports of good $X$ from country $j$. Governments are assumed to be able to commit to the taxes and tariffs they announce. For instance, if country $i$ offers a low $t_{i}$ to attract investment, it does not rescind its offer once the firm has made its investment. ${ }^{5}$ Profit taxes are chosen non-cooperatively throughout the paper. But which tariffs a country controls depends on the type of treaty it has signed with its potential partner country. If there is no trade agreement, $h$ and $l$ choose all their policy instruments simultaneously and non-cooperatively. If $h$ and $l$ form a free trade area, they eliminate internal tariffs $\left(r_{h l}=r_{l h}=0\right)$, but continue to set their tariffs on imports from $f$ independently. Most FTAs contain rules of origin. These rules determine what percentage of the value-added of a good must be produced in a member country of the free-trade area in order for the good to qualify for preferential access to the other member countries. The current paper focuses on the case where such rules are in place, meaning that the exemption from tariffs only applies to goods produced in the partner country. ${ }^{6}$ A customs union implies that the two countries eliminate bilateral tariffs and set a common external tariff $\left(r_{h f}=r_{l f}=r_{f}\right)$.

\footnotetext{
${ }^{3}$ In a CU or FTA the firm will set the same price in both $h$ and $l$ in equilibrium; for the analysis of the preferential trade area itself the assumption of segmented markets is therefore not important.

${ }^{4}$ This is consistent with the assumption that the firm is wholly foreign owned: the government of country $f$ cannot raise social welfare by taxing its firm.

${ }^{5}$ The commitment problem and its effect on FDI has been extensively discussed in the literature [see, for instance, Bond and Samuelson (1988), and Doyle and van Wijnbergen (1994)]. The current paper has nothing new to add to this literature, and I avoid the commitment problem by assuming that the costs associated with operating a plant are fixed but not sunk.

${ }^{6}$ In a FTA without rules of origin, all goods shipped between $h$ and $l$ are tariff free independently of where they originated, thus allowing the firm to supply the area via the country with the lowest external tariff. In equilibrium, tariff revenue competition between $h$ and $l$ drives their external tariffs down to zero. The resulting social welfare is strictly lower than the one a country can obtain with rules of origin.
} 
The strategic interaction between $h, l$ and the firm can be represented by a sequential game with the following order of moves:

Stage 0: $h$ and $l$ decide whether or not to form a FTA or CU. When the latter option is selected, $h$ and $l$ choose their common external tariff.

Stage 1: $h$ and $l$ choose profit taxes and available tariffs simultaneously and noncooperatively.

Stage 2: The firm observes these policies and decides how to supply each country.

Stage 3: The firm chooses prices for each country.

The subgame perfect equilibria of this game (equilibria for short) can be characterized using backward induction; I focus on pure-strategy equilibria.

\section{Preliminary Steps}

To illustrate the firm's choice of prices in the last stage of the game consider a scenario in which the firm operates a plant in country $i$ (where it is taxed at rate $t_{i}$ ), sells output locally in $i$ and exports to $j$ (where the tariff on imports from $i$ is $\left.r_{j i}\right)$. The firm then solves the following maximization problem:

$$
\max _{p_{i}, p_{j}}\left(1-t_{i}\right)\left[\left(p_{i}-c_{i}\right)\left(1-p_{i}\right)+\left(p_{j}-c_{i}-r_{j i}\right)\left(1-p_{j}\right)-G\right] .
$$

The profit-maximizing prices in markets $i$ and $j$ are $p_{i}\left(c_{i}\right)=\left(1+c_{i}\right) / 2$ and $p_{j}\left(c_{i}, r_{j i}\right)=\left(1+c_{i}+r_{j i}\right) / 2$, respectively. The output sold in country $i$ is $x_{i}\left(c_{i}\right)=\left(1-c_{i}\right) / 2$; and $x_{j i}\left(c_{i}, r_{j i}\right)=\left(1-c_{i}-r_{j i}\right) / 2$ is the quantity exported to $j$. The firm's after-tax profit is

$$
\Pi_{i}\left(r_{j i}, t_{i}, c_{i}, G\right)=\left(1-t_{i}\right)\left[\frac{\left(1-c_{i}\right)^{2}}{4}+\frac{\left(1-c_{i}-r_{j i}\right)^{2}}{4}-G\right] .
$$

The firm's location decision in stage 2 of the game is based on a comparison of the after-tax profits associated with all possible location choices. In stage 1, each government selects tax and tariff policies to maximize social welfare taking as given the policy choice of the other country and taking into account how its strategy will affect the firm's location decision and prices. For example, social welfare in country $i$ in the scenario where the firm locates in $i$ and also supplies $j$ from there is 


$$
U_{i}\left(r_{j i}, t_{i}, c_{i}, G\right)=\frac{\left(1-c_{i}\right)^{2}}{8}+t_{i}\left[\frac{\left(1-c_{i}\right)^{2}}{4}+\frac{\left(1-c_{i}-r_{j i}\right)^{2}}{4}-G\right],
$$

where the first term represents consumer surplus and the second term tax revenue. On the other hand, if the firm locates in country $j$ and $i$ imports $X$ from $j$ and levies a tariff at rate $r_{i j}$, social welfare is

$$
U_{i}\left(r_{i j}, c_{j}\right)=\frac{\left(1-c_{j}-r_{i j}\right)^{2}}{8}+r_{i j} \frac{\left(1-c_{j}-r_{i j}\right)}{2}
$$

where the first term again is consumer surplus and the second term is tariff revenue.

Before analyzing the equilibrium policy choices when the firm is mobile, it is helpful to first examine policy responses if the firm's location is fixed. These policies can then serve as a reference point for the subsequent analysis. If $\Pi_{i}\left(r_{j i}, t_{i}, c_{i}, G\right)>0$, government $i$ 's best tax policy would be to set its maximum tax rate $\left(t_{i}=1\right)$ in order to extract all of the profit that would otherwise be transferred to the firm's owners in $f$. If country $i$ imports $X$ from country $j$, its "unconstrained" optimal tariff on these imports is obtained by maximizing $U_{i}\left(r_{i j}, c_{j}\right)$ in $(7)$ over $r_{i j}$. This tariff is $r_{i j}^{*} \equiv\left(1-c_{j}\right) / 3$, the associated welfare is $U_{i}\left(r_{i j}^{*}, c_{j}\right)=\left(1-c_{j}\right)^{2} / 6$ and the firm's profit from exporting to $i$ (gross of fixed cost) is $\Pi_{j}\left(r_{i j}^{*}, c_{j}\right)=\left(1-c_{j}\right)^{2} / 9$.

Finally I make the following assumption:

$$
\text { Assumption } 1: \frac{5}{8}\left(1-c_{h}\right)^{2}-G>\frac{1}{8}\left(1-c_{l}\right)^{2}
$$

Assumption 1 implies that in a FTA $h$ would prefer having the firm locate in the country rather than in $l$, provided that it can capture through its tax the firm's entire profit of supplying the FTA. This assumption also implies that in the absence of tariffs and taxes the firm could profitably supply $h$ and $l$ from a plant in $h$.

\section{Equilibria Without Preferential Trade}

In this benchmark scenario $h$ and $l$ each have three policy instruments (the profit tax and tariffs on imports from each of the two other countries). There are two basic courses of action that a government can pursue. First, by making both tariffs prohibitively high, it may force the firm to set up a production facility in the country; it can then tax its profits at the maximum rate. Second, it may induce the firm to set up a plant 
in another country (for instance, by levying a prohibitively high tax) and then impose its optimal tariff on imports. Prohibitive taxes and tariffs are not uniquely defined in the model. However, for notational convenience let $\bar{t}_{i}$ denote an arbitrary "prohibitive tax" for country $i$ and $\bar{r}_{i j}$ an arbitrary "prohibitive" tariff by country $i$ on imports from country $j$. Furthermore, let $T_{i}^{\max }$ denote the maximum tax revenue $i$ can extract from the firm.

Now consider possible equilibrium policies and location choices. Both $h$ and $l$ will prevent FDI and impose their unconstrained optimal tariffs on imports from $f$, if the associated welfare, $U_{i}\left(r_{i f}^{*}, c_{f}\right)=\left(1-c_{f}\right)^{2} / 6$, exceeds the welfare that could be generated through a unilateral deviation. For country $l$ the relevant deviation consists of inducing FDI via prohibitive tariffs and taxing the firm. This deviation would yield consumer surplus of $\left(1-c_{l}\right)^{2} / 8$ and tax revenue. If the firm were able to generate a positive gross profit in $l$, the maximum tax revenue $l$ could earn by setting $t_{l}=1$ would be $\left(1-c_{l}\right)^{2} / 4-G+\max \left\{0,\left[\left(1-c_{l}\right)^{2}-\left(1-c_{f}\right)^{2}\right] / 9\right\}$, where the first part consists of the profits on sales in $l$ (net of the fixed cost), and the second part is the firm's excess profit from supplying $h$ from $l$ rather than $f$, which is positive if $c_{l}<c_{f}$. Hence the following condition is sufficient to rule out this deviation:

$$
\frac{1}{6}\left(1-c_{f}\right)^{2} \geq \frac{3}{8}\left(1-c_{l}\right)^{2}-G+\max \left\{0, \frac{1}{9}\left[\left(1-c_{l}\right)^{2}-\left(1-c_{f}\right)^{2}\right]\right\}
$$

Moreover, if this deviation is unprofitable for $l$, then it must also be unprofitable for $h$, as $h$ would obtain lower consumer surplus and lower tax revenue from the deviation than $l$. The condition requires $c_{f}$ to be small compared to $c_{l}$, and $G$ to be large.

An equilibrium in which only $l$ attracts FDI is obtained if (i) $h$ prefers importing from either $l$ or $f$ and levying its respective unconstrained optimal tariff to obtaining FDI and taxing the firm at the maximum rate, i.e.,

$$
\frac{1}{6} \max \left\{\left(1-c_{l}\right)^{2},\left(1-c_{f}\right)^{2}\right\} \geq \frac{3}{8}\left(1-c_{h}\right)^{2}-G ;
$$

and (ii) $l$ prefers attracting FDI to importing from $f$ :

$$
\frac{1}{8}\left(1-c_{l}\right)^{2}+T_{l}^{\max } \geq \frac{1}{6}\left(1-c_{f}\right)^{2} .
$$

Note that $T_{l}^{\max }$ in this case is at most $\left(1-c_{l}\right)^{2} / 4-G+\max \left\{0, \frac{1}{9}\left[\left(1-c_{l}\right)^{2}-\left(1-c_{f}\right)^{2}\right]\right\}$. This equilibrium occurs, if $c_{l}$ is small relative to $c_{f}$ and $c_{h}$, and $G$ is not too large. There is obviously no equilibrium in which only $h$ obtains FDI. 
A sufficient condition for $h$ and $l$ to both attract FDI in equilibrium is that for $h$ the sum of consumer surplus and tax revenue if the firm invests and sells in $h$, i.e., $\left(1-c_{h}\right)^{2} / 8+T_{h}^{\max }$, is higher than the welfare it can obtain when levying the unconstrained optimal tariff on imports from either $f$ or $l$, i.e.,

$$
\frac{1}{8}\left(1-c_{h}\right)^{2}+T_{h}^{\max } \geq \frac{1}{6} \max \left\{\left(1-c_{l}\right)^{2},\left(1-c_{f}\right)^{2}\right\}
$$

where $T_{h}^{\max }$ is at most equal to $\left(1-c_{h}\right)^{2} / 4-G$ in this equilibrium. If this is true for $h$ it will also be true for $l$. Hence for this type of equilibrium to exist $c_{h}$ and $c_{l}$ must be low compared to $c_{f}$ and $G$ must be small.

\section{Equilibria in a Free Trade Area}

If $h$ and $l$ form a FTA, how will this affect taxes and external tariffs and the firm's location decision? I begin by proposing an equilibrium in which FDI occurs in the FTA. This equilibrium will then serve as a reference point for discussing questions of existence and uniqueness and for comparing changes in location and taxation relative to the case without preferential trade. A few features of this equilibrium are easily ascertained. First, in the absence of internal tariffs and given the economies of scale generated by the fixed cost, the firm will locate at most one plant in the FTA. Second, if it does invest, it will do so in $l$.

Now suppose that there is a plant in $l$. If $h$ imported from $l$, its social welfare would be equal to consumer surplus, $\left(1-c_{l}\right)^{2} / 8$. Country $h$ could also try to induce the firm to relocate to $h$ and serve both FTA markets from there; it would then obtain a social welfare of

$$
\frac{\left(1-c_{h}\right)^{2}}{8}+t_{h}\left[\frac{\left(1-c_{h}\right)^{2}}{2}-G\right]
$$

The fact that consumer surplus is higher when goods are imported from $l$ than when they are produced locally puts a lower limit on the tax rate that $h$ would be willing to offer to induce FDI. In particular, $t_{h}$ has to be high enough such that

$$
\frac{\left(1-c_{h}\right)^{2}}{8}+t_{h}\left[\frac{\left(1-c_{h}\right)^{2}}{2}-G\right] \geq \frac{\left(1-c_{l}\right)^{2}}{8} .
$$

This inequality is satisfied strictly for $t_{h}=1$ by Assumption 1 , and violated for $t_{h}=0$. Moreover, since the left-hand side is monotonically increasing in $t_{h}$, there exists a critical value $\hat{t}_{h} \in(0,1)$ for which $(13)$ holds with equality: 


$$
\hat{t}_{h}=\frac{\left(1-c_{l}\right)^{2}-\left(1-c_{h}\right)^{2}}{4\left[\left(1-c_{h}\right)^{2}-2 G\right]} .
$$

Given $\hat{t}_{h}$ and a rate $t_{l}$ imposed by country $l$, the firm is indifferent between locating in $h$ and locating in $l$ to supply the FTA, if

$$
\left(1-\hat{t}_{h}\right)\left[\frac{\left(1-c_{h}\right)^{2}}{2}-G\right]=\left(1-t_{l}\right)\left[\frac{\left(1-c_{l}\right)^{2}}{2}-G\right] .
$$

Hence, if $l$ wants to obtain investment and $h$ 's tax is $\hat{t}_{h}$, its tax rate must leave the firm at least as much profit as it could earn if it supplied the FTA from a plant in $h$. Solving (15) for $t_{l}$ and denoting the solution by $\hat{t}_{l}$ we have

$$
\hat{t}_{l}=\frac{5\left[\left(1-c_{l}\right)^{2}-\left(1-c_{h}\right)^{2}\right]}{4\left[\left(1-c_{l}\right)^{2}-2 G\right]} .
$$

Now consider the following type of equilibrium: $h$ sets a prohibitive tariff $\bar{r}_{h f}$ against $f$ and levies a tax at rate $\hat{t}_{h} ; l$ also imposes a prohibitive tariff $\bar{r}_{l f}$ on imports from $f$ and levies a tax at rate $\hat{t}_{l}$; on the equilibrium path the firm locates a plant $l$ to supply both $h$ and $l .^{7}$ In this equilibrium the firm would earn a profit of

$$
\hat{\Pi}_{l} \equiv \frac{5}{8}\left(1-c_{h}\right)^{2}-\frac{1}{8}\left(1-c_{l}\right)^{2}-G,
$$

which is positive by Assumption 1. The two countries would obtain social welfare of

$$
\hat{U}_{h} \equiv \frac{1}{8}\left(1-c_{l}\right)^{2}
$$

and

$$
\hat{U}_{l} \equiv \frac{6}{8}\left(1-c_{l}\right)^{2}-\frac{5}{8}\left(1-c_{h}\right)^{2},
$$

respectively.

Would any of the players gain from a deviation? In equilibrium, the firm is indifferent between locating in $h$ or $l$ and hence cannot gain from relocating to $h$; the prohibitive tariffs on imports from $f$ prevent it from

\footnotetext{
${ }^{7}$ Below I will write these equilibrium policies as $\left\langle\left(\bar{r}_{h f}, \hat{t}_{h}\right),\left(\bar{r}_{l f}, \hat{t}_{l}\right)\right\rangle$. The best responses of the firm off the equilibrium path can be easily derived and are hence omitted here.
} 
supplying the FTA from there. Given the prohibitive external tariffs, $\hat{t}_{h}$ and $\hat{t}_{l}$ are mutual best responses for the countries. This leaves deviations by $h$ or $l$ that involve changes in the external tariffs and induce the firm to switch its supply mode. In particular, we have to check if $h$ can do better by switching to a lower tariff $r_{h f}^{d}$ that allows it to import from $f$ instead of $l$. If we can rule out this deviation for $h$, it will also not be profitable for $l$ given that the latter has a higher equilibrium payoff. Deviating would not pay for $h$, if

$$
\frac{\left(1-c_{l}\right)^{2}}{8} \geq \max _{r_{h f}^{d}}\left\{\frac{\left(1-c_{f}-r_{h f}^{d}\right)^{2}}{8}+r_{h f}^{d} \frac{\left(1-c_{f}-r_{h f}^{d}\right)}{2}\right\},
$$

where $r_{f h}^{d}$ has to be low enough to induce the firm to supply $h$ from $f$ rather than $l$ given the latter's equilibrium policy, i.e.,

$$
\frac{\left(1-c_{f}-r_{h f}^{d}\right)^{2}}{4}+\max \left\{0,\left(1-\hat{t}_{l}\right)\left[\frac{\left(1-c_{l}\right)^{2}}{4}-G\right]\right\}>\hat{\Pi}_{l} .
$$

Whether (20) holds depends on the cost parameters. These parameters also determine which supply mode the firm chooses in the absence of preferential trade. It is therefore convenient to discuss the existence of this FDI equilibrium under the FTA simultaneously with the potential changes in location and taxation that it implies relative to the no-FTA case. There are three cases to consider. First, if in the absence of a FTA the firm served $h$ and $l$ through exports, it may now locate a plant in $l$; I refer to this case as one of FDI creation. Second, if the firm initially had plants in $h$ and/or $l$ before the FTA, it may now concentrate investment in $l$; I call this the FDI consolidation case. Third, the firm may shut down its plant(s) in $h$ and/or $l$, and supply the FTA through exports from $f$; this is a case of FDI destruction.

\subsection{FDI Creation}

Assume that (8) holds so that in the absence of a FTA no FDI occurs and social welfare in each country is $\left(1-c_{f}\right)^{2} / 6$. When does FDI occur under the FTA and how does this affect welfare? I consider two cases, depending on whether $h$ is better off importing tariff-free from $l$ than importing from $f$ and levying its unconstrained optimal tariff, i.e., whether or not

$$
\frac{1}{8}\left(1-c_{l}\right)^{2} \geq \frac{1}{6}\left(1-c_{f}\right)^{2}
$$

(8) and (22) together imply

$$
0>-\frac{1}{9}\left[\left(1-c_{l}\right)^{2}-\left(1-c_{f}\right)^{2}\right] \geq \frac{1}{4}\left(1-c_{l}\right)^{2}-G .
$$


That is, production costs in $h$ and $l$ are too high relative to local market size to sustain FDI in the absence of a FTA; in particular, given the positive tariffs levied by the other party in equilibrium, no government has an incentive to lower its taxes to induce FDI. This changes under the FTA. If (22) is satisfied, which is the case if $c_{l}$ is sufficiently smaller than $c_{f}$, then (20) holds for all possible $r_{h f}^{d}$, including, of course, those satisfying (21). Hence an equilibrium exists with policies $\left\langle\left(\bar{r}_{h f}, \hat{t}_{h}\right),\left(\bar{r}_{l f}, \hat{t}_{l}\right)\right\rangle$ and a plant in $l$.

By constructing an example one can prove that the strategies $\left\langle\left(\bar{r}_{h f}, \hat{t}_{h}\right),\left(\bar{r}_{l f}, \hat{t}_{l}\right)\right\rangle$ and investment by the firm in $l$ may still be part of an equilibrium, even if (22) does not hold. One has to check that (20) holds given (21). Note from (21) that the tougher is tax competition (and hence the smaller is $\hat{t}_{l}$ ) in the proposed equilibrium, the lower must $r_{h f}^{d}$ be if the firm is to have an incentive to supply $h$ from $f$. This can be seen more easily if one rewrites (21) as follows:

$$
\frac{\left(1-c_{f}-r_{h f}^{d}\right)^{2}}{4}>\left(1-\hat{t}_{l}\right) \min \left\{\frac{\left(1-c_{l}\right)^{2}}{4}, \frac{\left(1-c_{l}\right)^{2}}{2}-G\right\} .
$$

In other words, the lower is the welfare in the proposed equilibrium with FDI, the smaller, too, is the gain from deviating; this is what sustains the equilibrium. Let $c_{h}$ approach $c_{l}$ so that $\hat{t}_{l}$ approaches zero and let $\left(1-c_{l}\right)^{2} / 4-G>0$. Then from $(23)$ the firm will only switch to supplying $h$ from $f$, if $r_{h f}^{d}<\left(c_{l}-c_{f}\right)$. Next let $c_{l}=c_{f}$. Then $h$ 's welfare in equilibrium and its welfare from deviation would be equal if $r_{h f}^{d}=0$. The derivative of $h$ 's deviation payoff in (20) with respect to $r_{h f}^{d}$, evaluated at $r_{h f}^{d}=0$, is equal to $\left(1-c_{f}\right) / 4$ and thus positive. Hence for $r_{h f}^{d}<0$, as is required to induce the firm's switch of supply mode, $h$ 's deviation must yield a lower welfare than the proposed equilibrium.

The FDI equilibrium does not have to be unique in the sense that there may also exist an equilibrium, in which both $h$ and $l$ continue to set prohibitive taxes and optimal tariffs on imports from $f$, $\left\langle\left(r_{h f}^{*}, \bar{t}_{h}\right),\left(r_{l f}^{*}, \bar{t}_{l}\right)\right\rangle$, and the firm does not invest. The potential deviation that one has to check is whether $l$ would be better off raising its tariff to a prohibitive level and adjusting its profit tax to induce FDI; if one can rule this out for $l$, it will also not be profitable for $h$. The proposed deviation would yield a payoff equal to the sum of consumer surplus and tax revenue. This tax revenue is equal to the profit the firm could earn when locating in $l$ to serve the whole FTA, $\left(1-c_{l}\right)^{2} / 2-G$, minus the profit the firm would earn if it only exported to $h$ from $f$ at the unconstrained optimal tariff, $\left(1-c_{f}\right)^{2} / 9$. This deviation is unprofitable if

$$
\frac{5}{18}\left(1-c_{f}\right)^{2} \geq \frac{5}{8}\left(1-c_{l}\right)^{2}-G
$$

that is, if the production cost in $f$ is low enough relative to that in $l$. 
A sufficient condition for obtaining multiple equilibria, one with policies $\left\langle\left(\bar{r}_{h f}, \hat{t}_{h}\right),\left(\bar{r}_{l f}, \hat{t}_{l}\right)\right\rangle$ and FDI in $l$ and the other with policies $\left\langle\left(r_{h f}^{*}, \bar{t}_{h}\right),\left(r_{l f}^{*}, \bar{t}_{l}\right)\right\rangle$ and no FDI, is for (22) and (24) to hold simultaneously. This requires

$$
\frac{1}{9}\left(1-c_{f}\right)^{2} \geq \frac{1}{2}\left(1-c_{l}\right)^{2}-G
$$

that is, the firm's profit from exporting to $h$ from $f$ must exceed the profit of serving the whole FTA from $l .^{8}$

The following proposition summarizes the sufficient conditions for existence of an equilibrium:

Proposition 1 (a) If $c_{l}$ is sufficiently smaller than $c_{f}$ so that (22) holds, an equilibrium with $\left\langle\left(\bar{r}_{h f}, \hat{t}_{h}\right),\left(\bar{r}_{l f}, \hat{t}_{l}\right)\right\rangle$ and FDI in l exists. (b) If $c_{f}$ is low enough relative to $c_{l}$ so that (24) holds, there exists an equilibrium with policies $\left\langle\left(r_{h f}^{*}, \bar{t}_{h}\right),\left(r_{l f}^{*}, \bar{t}_{l}\right)\right\rangle$ and no FDI. (c) If (22) and (24) are satisfied, there exist multiple equilibria, one with policies $\left\langle\left(\bar{r}_{h f}, \hat{t}_{h}\right),\left(\bar{r}_{l f}, \hat{t}_{l}\right)\right\rangle$ and FDI in l and one with policies $\left\langle\left(r_{h f}^{*}, \bar{t}_{h}\right),\left(r_{l f}^{*}, \bar{t}_{l}\right)\right\rangle$ and no FDI.

Proposition 1 is illustrated by Figure 1, which identifies equilibria in $\left(c_{l}, c_{f}\right)$-space for $c_{h}=0.2$ and $G=0.3 .{ }^{9}$ In the regions labeled I to V (8) holds so that no FDI occurs in the absence of a FTA. Regions I and II correspond to the case analyzed in Proposition 1(a): (22) holds and thus an equilibrium with policies $\left\langle\left(\bar{r}_{h f}, \hat{t}_{h}\right),\left(\bar{r}_{l f}, \hat{t}_{l}\right)\right\rangle$ and FDI in $l$ exists. In regions III to V, $(22)$ does not hold; an FDI equilibrium does not exist for the values chosen for $c_{h}$ and $G$. In particular, $h$ has an incentive in these regions to lower its tariff so that the firm will want to supply it through exports from $f$, thus violating (20). Regions II, IV and V satisfy (24); they feature an equilibrium with policies $\left\langle\left(r_{h f}^{*}, \bar{t}_{h}\right),\left(r_{l f}^{*}, \bar{t}_{l}\right)\right\rangle$ and no FDI (Proposition 1(b)). In region II one obtains multiple equilibria (Proposition $1(\mathrm{c})) .{ }^{10}$

Next consider the welfare effects. If $c_{l}$ is sufficiently smaller than $c_{f}$ so that (22) is satisfied, FDI creation raises welfare in $h$ and $l$ despite the fact that there is tax competition to attract FDI. In fact, the gain in consumer surplus is reason enough to induce FDI in this case. If (22) is not satisfied, i.e., if $c_{l}$ is either larger or only slightly smaller than $c_{f}, h$ loses from FDI creation (in the absence of any offsetting transfers

\footnotetext{
${ }^{8}$ If only (24) holds, one can prove by example that these two types of equilibria may still coexist. An example that works is $c_{l}=0.2, c_{f}=0.3, G=0.3$ and $c_{h}$ close enough to $c_{l}$.

${ }^{9}$ This figure was generated by running simulations on the model with Maple. Given the values chosen for $c_{h}$ and $G$, Assumption 1 is satisfied for $c_{l}>0.106$.

${ }^{10}$ One can show that in region III there does not exist an equilibrium in pure strategies.
} 


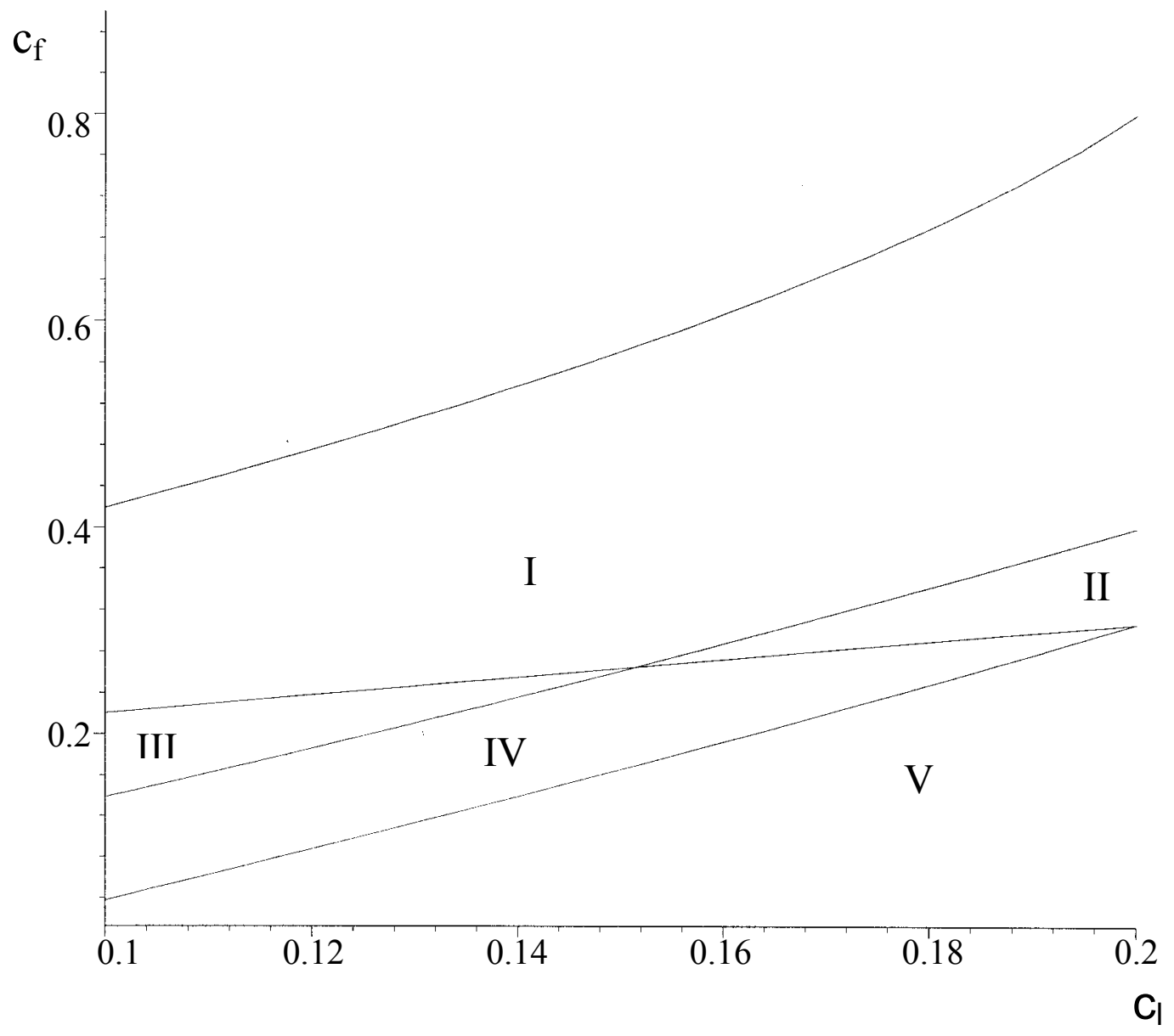

Figure 1: Equilibria for $\mathrm{c}_{\mathrm{h}}=0.2$ and $\mathrm{G}=0.3$ 
from $l) ; l$ gains or loses, depending on the difference between $c_{h}$ and $c_{l}$, as can be seen in (19). The smaller is $\left(c_{h}-c_{l}\right)$, the tougher is tax competition and the more likely it is that l's welfare decreases, too. This can also be seen in the condition for the joint welfare of $h$ and $l$ to be higher under FDI than when good $X$ is imported from $f$ and the countries can charge their unconstrained optimal tariffs:

$$
\frac{7}{8}\left(1-c_{l}\right)^{2}-\frac{5}{8}\left(1-c_{h}\right)^{2} \geq \frac{1}{3}\left(1-c_{f}\right)^{2}
$$

Condition (26) shows that the welfare effect of FDI creation rests on a trade-off between the efficiency gains in production and the revenue loss from tax competition. In particular, the tougher is tax competition, the lower the production cost in $l$ has to be relative to that in $f$, if FDI creation is to raise welfare. These welfare results may be summarized as follows:

Proposition 2 (a) If $c_{l}$ is sufficiently smaller than $c_{f}$ so that (22) holds, FDI creation raises the welfare of both $h$ and $l$. (b) If (22) is not satisfied, $h$ loses from FDI creation, but the joint welfare of $h$ and $l$ rises (and $l$ may hence compensate $h$ ), if tax competition is not too tough and the cost of production in $l$ is sufficiently low compared to that in $f$.

This proposition can also be illustrated by Figure 1. In regions I and II, FDI creation unambiguously raises the welfare of both $h$ and $l$. Note, however, that in region II one obtains multiple equilibria, with the FDI equilibrium Pareto-dominating the one without FDI; hence a FTA does not necessarily lead to FDI creation and welfare gains. Regions $\mathrm{IV}$ and $\mathrm{V}$ are divided by a line representing condition (26). In regions III and IV, the joint welfare of $h$ and $l$ would be higher if there were FDI, but the FDI equilibrium does not exist here.

Finally one can use Figure 1 to illustrate what the model has to say about how the effects of a FTA may differ from those of a CU, and about the occurrence of a FTA or CU. When local production in $h$ and $l$ offers a cost advantage relative to supplying these countries from the rest of the world as in region I, we should observe the formation of a FTA as this induces FDI and raises the welfare of the member countries. When this cost advantage is small or nonexistent as in regions II, III and IV, a FTA may fail to raise welfare. There are two reasons why a $\mathrm{CU}$, by allowing countries to coordinate on a common external tariff, may then do better. First, as in regions III and IV, a CU by setting a prohibitive common external tariff can create FDI and raise the joint welfare of $h$ and $l$. Second, even if the FDI equilibrium exists under a FTA as 
in region II, countries may be trapped in the Pareto-dominated equilibrium without FDI, unable to escape it without coordinating their external tariffs and/or profit taxes. A CU can then serve as an appropriate coordination device. Note, however, that if the cost difference between $h$ and $l$ is large, the formation of a CU would require side-payments between the member countries (regions III and IV). A CU should be easier to establish when this cost difference is small so that side-payments are not necessary (region II).

\subsection{FDI Consolidation and FDI Destruction}

Suppose the firm operated plants in both $h$ and $l$ before the FTA. The creation of a FTA will then lead the firm to close its plant in $h$, forcing the latter to import good $X$. But prior to the FTA $h$ already had the option of importing $X$ and was able to levy a tariff on imports from $l$. Hence $h$ cannot gain from a FTA unless it receives an offsetting transfer from $l .{ }^{11}$ The relevant question therefore is whether $l$ will benefit from the FTA and, if yes, whether the gain is large enough to compensate $h$ for its losses.

Prior to the FTA, $l$ received a maximum welfare (for a tax rate of $t_{l}=1$ ) of $3\left(1-c_{l}\right)^{2} / 8-G$. Under the FTA with equilibrium policies $\left\langle\left(\bar{r}_{h f}, \hat{t}_{h}\right),\left(\bar{r}_{l f}, \hat{t}_{l}\right)\right\rangle l$ 's welfare is given by (19). A welfare gain for $l$ from the FTA hence requires

$$
\frac{3}{8}\left(1-c_{l}\right)^{2}-\frac{5}{8}\left(1-c_{h}\right)^{2}+G \geq 0
$$

That is, $\left(c_{h}-c_{l}\right)$ and $G$ have to be sufficiently large. If $\left(c_{h}-c_{l}\right)$ is big, tax competition is low and $l$ can still levy a high tax despite the competition from $h$. A large $G$ implies big economies of scale, which can be better exploited in the FTA than in a small national market. The condition for joint welfare to increase under the FTA,

$$
\frac{1}{2}\left(1-c_{l}\right)^{2}-\left(1-c_{h}\right)^{2}+2 G>0
$$

holds under similar circumstances. This establishes the following result:

Proposition 3 If the firm initially had plants in both countries, the FTA will lead it to close its plant in $h$. Country $l$ benefits from the FTA and is able compensate $h$ for its welfare loss if tax competition is low and the fixed cost of FDI is sufficiently big.

\footnotetext{
${ }^{11}$ The same holds true, if only $l$ received FDI before the FTA, the reason again being that $h$ loses its ability to tax imports from $l$. This case is not explicitly examined here, since it is analogous to the one where both countries initially have FDI.
} 
Finally consider FDI destruction. If there exists an equilibrium in which FDI occurs prior to the creation of a FTA, then the reverse of inequality (8) must necessarily hold; that is, the maximum welfare $l$ can achieve from FDI must exceed the welfare generated by importing $X$ from $f$ :

$$
\frac{3}{8}\left(1-c_{l}\right)^{2}-G+\max \left\{0, \frac{1}{9}\left[\left(1-c_{l}\right)^{2}-\left(1-c_{f}\right)^{2}\right]\right\}>\frac{1}{6}\left(1-c_{f}\right)^{2}
$$

Now suppose that under the FTA there is an equilibrium with policies $\left\langle\left(r_{f}^{*}, \bar{t}_{h}\right),\left(r_{f}^{*}, \bar{t}_{l}\right)\right\rangle$ and no FDI. Then (24) must hold. But (29) and (24) together yield a contradiction. Hence one may state the following proposition:

Proposition 4 The formation of a FTA cannot lead to FDI destruction where the firm closes its plant(s) in the FTA, and $h$ and $l$ import from $f$ levying their unconstrained optimal tariffs.

The intuition is that if $l$ found it attractive to induce FDI when the firm from its plant in $l$ could only supply the local market or at least faced tariffs when exporting to $h$, it will also want to attract FDI when the firm can export to $h$ tariff-free.

\section{Extensions}

If the cost of production in $l$ is only slightly smaller or even larger than in $f$ (so that (22) is not satisfied), a preferential trade agreement (PTA) — FTA or a CU—cannot raise and will typically reduce $h$ 's welfare, irrespective of whether it induces FDI creation or FDI consolidation. A PTA will hence only come about, if $l$ 's gains are large enough to compensate $h$; these gains are increasing in $\left(c_{h}-c_{l}\right)$ and, in the case of FDI consolidation, also in $G$. But what happens, if the required side-payments are not feasible? As I demonstrate in this section, by relaxing the assumption that the firm is wholly owned by residents of country $f$, it is possible for a PTA to directly benefit both $h$ and $l$ even in the absence of any side-payments. In particular, if residents of $h$ hold a sufficiently large stake in the firm, the creation of a PTA may raise their welfare indirectly by limiting the tax that country $l$ is able to collect from the firm.

Let $\alpha_{i}>0$ denote the fraction of the firm's profit claimed by residents of country $i=h, l$ and let $\alpha_{h}+\alpha_{l}<1$, so that a positive fraction of profits is claimed by residents of $f$. This ensures that $h$ and $l$ would still like to set their taxes so as to extract as much as possible of the firm's profit and redistribute this 
revenue to their own residents. Now suppose that $h$ and $l$ have formed a PTA and that in equilibrium the firm has a plant in $l$. What are the equilibrium tax rates? Importing good $X$ from that plant would yield $h$ welfare equal to the sum of consumer surplus and a share $\alpha_{h}$ of the firm's after-tax profit:

$$
\frac{\left(1-c_{l}\right)^{2}}{8}+\alpha_{h}\left(1-t_{l}\right)\left[\frac{\left(1-c_{l}\right)^{2}}{2}-G\right]
$$

If the firm located in $h$ to supply the PTA, $h$ 's welfare would consist of the sum of consumer surplus, tax revenue and its share of the firm's after-tax profits:

$$
\frac{\left(1-c_{h}\right)^{2}}{8}+t_{h}\left[\frac{\left(1-c_{h}\right)^{2}}{2}-G\right]+\alpha_{h}\left(1-t_{h}\right)\left[\frac{\left(1-c_{h}\right)^{2}}{2}-G\right]
$$

The smallest tax $h$ would be willing to offer the firm is the one that would make it indifferent between (31) and (30); denote this tax by $t_{h}^{\prime}$. In addition, the highest tax that $l$ can impose and still receive FDI when $h$ levies tax $t_{h}^{\prime}$ is given by $t_{l}^{\prime}$, where

$$
\left(1-t_{h}^{\prime}\right)\left[\frac{\left(1-c_{h}\right)^{2}}{2}-G\right]=\left(1-t_{l}^{\prime}\right)\left[\frac{\left(1-c_{l}\right)^{2}}{2}-G\right] .
$$

Solving (30), (31) and (32) for the equilibrium tax rates one observes the following:

Proposition 5 Suppose there is a PTA and there exists an equilibrium in which the firm supplies the PTA from a plant in $l$. Then the equilibrium tax rates are given by $\hat{t}_{h}$ and $\hat{t}_{l}$ in (14) and (16); equilibrium taxes are hence independent of the firm's ownership structure as long as it is partly owned by residents of $f$.

This result is convenient, since one can now use changes in the $\alpha_{i}$ 's to shift welfare between residents of $h$ and $l$ without affecting the location and price choices of the firm. Equilibrium welfare in $h$ is

$$
\frac{\left(1-c_{l}\right)^{2}}{8}+\alpha_{h}\left[\frac{5\left(1-c_{h}\right)^{2}-\left(1-c_{l}\right)^{2}}{8}-G\right]
$$

whereas welfare in $l$ is

$$
\left(6-\alpha_{l}\right) \frac{\left(1-c_{l}\right)^{2}}{8}-\left(1-\alpha_{l}\right) \frac{5\left(1-c_{h}\right)^{2}}{8}-\alpha_{l} G
$$

both are increasing in the respective $\alpha_{i}$. The joint welfare of $h$ and $l$ is increasing in $\left(\alpha_{h}+\alpha_{l}\right)$. So if a PTA raises joint welfare when the firm is completely foreign owned $\left(\alpha_{h}=\alpha_{l}=0\right)$, it must also do so if $\alpha_{h}+\alpha_{l}>0$. 
Suppose that the PTA has led to FDI consolidation, with the firm closing its plant in $h$. The latter still benefits from the PTA, if the sum of consumer surplus and the share of the firm's after-tax profit claimed by its residents exceeds welfare prior to the PTA:

$$
\frac{\left(1-c_{l}\right)^{2}}{8}+\alpha_{h}\left[\frac{5\left(1-c_{h}\right)^{2}}{8}-\frac{\left(1-c_{l}\right)^{2}}{8}-G\right]>\frac{3\left(1-c_{h}\right)^{2}}{8}-G
$$

By Assumption 1, the left-hand side of this inequality is monotonically increasing in $\alpha_{h}$. The inequality is satisfied if $\alpha_{h}$ is equal to one, but it is violated if $\alpha_{h}$ is zero. There hence exists a critical value of $\alpha_{h}$, denoted by $\bar{\alpha}_{h}$, where

$$
\bar{\alpha}_{h}=\frac{3\left(1-c_{h}\right)^{2}-\left(1-c_{l}\right)^{2}-8 G}{5\left(1-c_{h}\right)^{2}-\left(1-c_{l}\right)^{2}-8 G}>0
$$

such that for $\alpha_{h}>\bar{\alpha}_{h}, h$ is strictly better off under a FTA.

Finally suppose that the PTA led to FDI creation. If country $i$ imports $X$ from $f$, its unconstrained optimal tariff is determined by the following maximization problem:

$$
\max _{r_{i f}}\left\{\frac{\left(1-c_{f}-r_{i f}\right)^{2}}{8}+\alpha_{i} \frac{\left(1-c_{f}-r_{i f}\right)^{2}}{4}+r_{i}^{f} \frac{\left(1-c_{f}-r_{i f}\right)}{2}\right\}
$$

where the first term represents consumer surplus, the second the local residents' share of the firm's operating profit in $f$ and the third tariff revenue. The associated optimal tariff is $r_{i f}^{\alpha} \equiv\left(1-c_{f}\right)\left(1-2 \alpha_{i}\right) /\left(3-2 \alpha_{i}\right)$, and the corresponding welfare for $i$ is

$$
U_{i}\left(w_{f}, r_{i f}^{\alpha}\right)=\frac{3\left(1-c_{f}\right)^{2}}{2\left(3-2 \alpha_{i}\right)^{2}}
$$

Therefore $h$ benefits from the PTA, if

$$
\frac{\left(1-c_{l}\right)^{2}}{8}+\alpha_{h}\left[\frac{5\left(1-c_{h}\right)^{2}}{8}-\frac{\left(1-c_{l}\right)^{2}}{8}-G\right]>\frac{3\left(1-c_{f}\right)^{2}}{2\left(3-2 \alpha_{h}\right)^{2}}
$$

\section{Conclusions}

This paper examined the effects of preferential trade on the location choice of a foreign investor, tax competition and social welfare. It was shown that a FTA may lead to FDI creation or consolidation, but typically 
not to FDI destruction. For FDI creation to occur the production costs in $h$ and $l$ must be in an intermediate range relative to the production costs in the rest of the world. In particular, they must be sufficiently large so that in the absence of free internal trade countries individually prefer to rely on imports from the rest of the world. But they must be small enough so that when markets are integrated in the FTA no country has an incentive to deter FDI. FDI creation represents a Pareto improvement irrespective of the degree of tax competition, if the production cost in the low-cost country in the FTA is sufficiently lower than that in the rest of the world, so that the high-cost country is not hurt if it has to import the good from its partner country rather than from the rest of the world. However, even if this is not the case and trade deflection hurts the high-cost country, a FTA may still raise the aggregate welfare of its members. This happens if the cost differential within the FTA is sufficiently large (and hence the degree of tax competition small) and the production cost in the low-cost location in the FTA is sufficiently low compared to that in the rest of the world.

If the cost advantage of the potential FTA relative to the rest of the world is small or nonexistent, a FTA may fail to induce FDI, even if it is welfare improving. There are two reasons why this may happen. First, there may be multiple equilibria and the countries may fail to coordinate on an equilibrium with FDI. Second, the high-cost country may have an incentive to deviate from an FDI equilibrium by reducing its external tariff so that the firm supplies it from the rest of the world. In both cases, a CU can bring about FDI and thus improve welfare, as it allows the countries to coordinate on the appropriate common external tariff.

If the firm had invested in both countries of the potential FTA, then integration will lead to FDI consolidation. Moreover, tax competition will force tax rates down in the FTA. Yet, the FTA will still raise joint welfare of the member countries, if the fixed cost of investment is large and the cost differential (degree of tax competition) within the FTA is sufficiently big (small).

Finally, the paper considered an extension where the firm was also partly owned by residents of the FTA or $\mathrm{CU}$ and showed that this does not affect equilibrium tax rates. Residents of the high-cost country may now benefit from a preferential trade agreement (even if they did not under full foreign ownership of the firm), because the resulting tax competition raises the firm's after-tax profit, of which they collect a share. 


\section{References}

[1] Benassy-Quere, A., L. Fontagne and A. Lahreche-Revil (2000), "Foreign Direct Investment and the Prospects for Tax Coordination in Europe," CEPII Document de travail No. 2000-06.

[2] Bond, E.W. and S.E. Guisinger (1985), "Investment Incentives as Tariff Substitutes: A Comprehensive Measure of Protection," Review of Economics and Statistics 67, 91-97.

[3] Bond, E.W. and L. Samuelson (1988), "Bargaining with Commitment, Choice of Techniques and Direct Foreign Investment," Journal of International Economics 26, 257-279.

[4] Davies, R. (2001), "State Tax Competition for Foreign Direct Investment: A Winnable War?" University of Oregon Working Paper No. 228.

[5] Donnenfeld, S. (1998), "Regional Trading Blocs and Foreign Direct Investment," York University, mimeo.

[6] Doyle, C. and S. van Wijnbergen (1994), "Taxation of Foreign Multinationals: A Sequential Bargaining Approach to Tax Holidays," International Tax and Public Finance 1, 211-225.

[7] Ethier, W.J. (1998), "Regionalism in a Multilateral World," Journal of Political Economy 106, 12141245 .

[8] Gordon, R.H. and J.R. Hines (2002), "International Taxation," NBER Working Paper No. 8854.

[9] Haufler, A. and A. Wooton (1999), "Country Size and Tax Competition for Foreign Direct Investment," Journal of Public Economics 71, 121-139.

[10] Hines, J.R. (1996), "Altered States: Taxes and the Location of Foreign Direct Investment in America," American Economic Review 86, 1076-1094.

[11] Horstmann, I.J. and J.R. Markusen (1992), "Endogenous Market Structure in International Trade (Natura Facit Saltum)," Journal of International Economics 32, 109-129.

[12] Janeba, E. (1998), "Tax Competition in Imperfectly Competitive Markets," Journal of International Economics 44, 135-153. 
[13] Keen, M. (1999), "Preferential Regimes Can Make Tax Competition Less Harmful," mimeo.

[14] Motta, M. and G. Norman (1996), "Does Economic Integration Cause Foreign Direct Investment?" International Economic Review 37, 757-783.

[15] Neary, P. (2001), "Foreign Direct Investment and the Single Market," University College Dublin, mimeo.

[16] Niosi, J. (1994), "Foreign Direct Investment in Canada," in: L. Eden (ed.), Multinationals in North America, Calgary: University of Calgary Press.

[17] Oman, C. (2000), Policy Competition for Foreign Direct Investment, A Study of Competition among Governments to Attract FDI, Paris: OECD.

[18] Pain, N. (1997), "Continental Drift: European Integration and the Location of U.K. Foreign Direct Investment," The Manchester School, Supplement 65, 94-117.

[19] Royal Commission on the Economic Union and Development Prospects of Canada (1985), Report, Vol. I, Ottawa: Minister of Supply and Services.

[20] UNCTAD (1996), Incentives and Foreign Direct Investment, New York: United Nations.

[21] Wilson, J.D. (1999), "Theories of Tax Competition," National Tax Journal 52, 269-304. 


\section{CESifo Working Paper Series}

692 Amihai Glazer, Vesa Kanniainen, and Mikko Mustonen, Innovation of Network Goods: A Non-Innovating Firm Will Gain, March 2002

693 Helmuth Cremer, Jean-Marie Lozachmeur, and Pierre Pestieau, Social Security, Retirement Age and Optimal Income Taxation, April 2002

694 Rafael Lalive and Josef Zweimüller, Benefit Entitlement and the Labor Market: Evidence from a Large-Scale Policy Change, April 2002

695 Hans Gersbach, Financial Intermediation and the Creation of Macroeconomic Risks, April 2002

696 James M. Malcomson, James W. Maw, and Barry McCormick, General Training by Firms, Apprentice Contracts, and Public Policy, April 2002

697 Simon Gächter and Arno Riedl, Moral Property Rights in Bargaining, April 2002

698 Kai A. Konrad, Investment in the Absence of Property Rights: The Role of Incumbency Advantages, April 2002

699 Campbell Leith and Jim Malley, Estimated General Equilibrium Models for the Evaluation of Monetary Policy in the US and Europe, April 2002

700 Yin-Wong Cheung and Jude Yuen, Effects of U.S. Inflation on Hong Kong and Singapore, April 2002

701 Henry Tulkens, On Cooperation in Musgravian Models of Externalities within a Federation, April 2002

702 Ralph Chami and Gregory D. Hess, For Better or For Worse? State-Level Marital Formation and Risk Sharing, April 2002

703 Fredrik Andersson and Kai A. Konrad, Human Capital Investment and Globalization in Extortionary States, April 2002

704 Antonis Adam and Thomas Moutos, The Political Economy of EU Enlargement: Or, Why Japan is not a Candidate Country?, April 2002

705 Daniel Gros and Carsten Hefeker, Common Monetary Policy with Asymmetric Shocks, April 2002

706 Dirk Kiesewetter and Rainer Niemann, Neutral and Equitable Taxation of Pensions as Capital Income, April 2002

707 Robert S. Chirinko, Corporate Taxation, Capital Formation, and the Substitution Elasticity between Labor and Capital, April 2002 
708 Frode Meland and Gaute Torsvik, Structural Adjustment and Endogenous Worker Recall Probabilities, April 2002

709 Rainer Niemann and Caren Sureth, Taxation under Uncertainty - Problems of Dynamic Programming and Contingent Claims Analysis in Real Option Theory, April 2002

710 Thomas Moutos and William Scarth, Technical Change and Unemployment: Policy Responses and Distributional Considerations, April 2002

711 Günther Rehme, (Re-)Distribution of Personal Incomes, Education and Economic Performance Across Countries, April 2002

712 Thorvaldur Gylfason and Gylfi Zoega, Inequality and Economic Growth: Do Natural Resources Matter?, April 2002

713 Wolfgang Leininger, Contests over Public Goods: Evolutionary Stability and the FreeRider Problem, April 2002

714 Ernst Fehr and Armin Falk, Psychological Foundations of Incentives, April 2002

715 Giorgio Brunello, Maria Laura Parisi, and Daniela Sonedda, Labor Taxes and Wages: Evidence from Italy, May 2002

716 Marta Aloi and Huw Dixon, Entry Dynamics, Capacity Utilisation and Productivity in a Dynamic Open Economy, May 2002

717 Paolo M. Panteghini, Asymmetric Taxation under Incremental and Sequential Investment, May 2002

718 Ben J. Heijdra, Christian Keuschnigg, and Wilhelm Kohler, Eastern Enlargement of the EU: Jobs, Investment and Welfare in Present Member Countries, May 2002

719 Tapio Palokangas, The Political Economy of Collective Bargaining, May 2002

720 Gilles Saint-Paul, Some Evolutionary Foundations for Price Level Rigidity, May 2002

721 Giorgio Brunello and Daniela Sonedda, Labor Tax Progressivity, Wage Determination, and the Relative Wage Effect, May 2002

722 Eric van Damme, The Dutch UMTS-Auction, May 2002

723 Paolo M. Panteghini, Endogenous Timing and the Taxation of Discrete Investment Choices, May 2002

724 Achim Wambach, Collusion in Beauty Contests, May 2002

725 Dominique Demougin and Claude Fluet, Preponderance of Evidence, May 2002

726 Gilles Saint-Paul, Growth Effects of Non Proprietary Innovation, May 2002 
727 Subir Bose, Gerhard O. Orosel, and Lise Vesterlund, Optimal Pricing and Endogenous Herding, May 2002

728 Erik Leertouwer and Jakob de Haan, How to Use Indicators for 'Corporatism' in Empirical Applications, May 2002

729 Matthias Wrede, Small States, Large Unitary States and Federations, May 2002

730 Christian Schultz, Transparency and Tacit Collusion in a Differentiated Market, May 2002

731 Volker Grossmann, Income Inequality, Voting Over the Size of Public Consumption, and Growth, May 2002

$732 \mathrm{Yu}-\mathrm{Fu}$ Chen and Michael Funke, Working Time and Employment under Uncertainty, May 2002

733 Kjell Erik Lommerud, Odd Rune Straume, and Lars Sørgard, Downstream Merger with Oligopolistic Input Suppliers, May 2002

734 Saku Aura, Does the Balance of Power Within a Family Matter? The Case of the Retirement Equity Act, May 2002

735 Sandro Brusco and Fausto Panunzi, Reallocation of Corporate Resources and Managerial Incentives in Internal Capital Markets, May 2002

736 Stefan Napel and Mika Widgrén, Strategic Power Revisited, May 2002

737 Martin W. Cripps, Godfrey Keller, and Sven Rady, Strategic Experimentation: The Case of Poisson Bandits, May 2002

738 Pierre André Chiappori and Bernard Salanié, Testing Contract Theory: A Survey of Some Recent Work, June 2002

739 Robert J. Gary-Bobo and Sophie Larribeau, A Structural Econometric Model of Price Discrimination in the Mortgage Lending Industry, June 2002

740 Laurent Linnemer, When Backward Integration by a Dominant Firm Improves Welfare, June 2002

741 Gebhard Kirchgässner and Friedrich Schneider, On the Political Economy of Environmental Policy, June 2002

742 Christian Keuschnigg and Soren Bo Nielsen, Start-ups, Venture Capitalits, and the Capital Gains Tax, June 2002

743 Robert Fenge, Silke Uebelmesser, and Martin Werding, Second-best Properties of Implicit Social Security Taxes: Theory and Evidence, June 2002

744 Wendell Fleming and Jerome Stein, Stochastic Optimal Control, International Finance and Debt, June 2002 
745 Gene M. Grossman, The Distribution of Talent and the Pattern and Consequences of International Trade, June 2002

746 Oleksiy Ivaschenko, Growth and Inequality: Evidence from Transitional Economies, June 2002

747 Burkhard Heer, Should Unemployment Benefits be Related to Previous Earnings?, July 2002

748 Bas van Aarle, Giovanni Di Bartolomeo, Jacob Engwerda, and Joseph Plasmans, Staying Together or Breaking Apart: Policy-makers' Endogenous Coalitions Formation in the European Economic and Monetary Union, July 2002

749 Hans Gersbach, Democratic Mechanisms: Double Majority Rules and Flexible Agenda Costs, July 2002

750 Bruno S. Frey and Stephan Meier, Pro-Social Behavior, Reciprocity or Both?, July 2002

751 Jonas Agell and Helge Bennmarker, Wage Policy and Endogenous Wage Rigidity: A Representative View From the Inside, July 2002

752 Edward Castronova, On Virtual Economies, July 2002

753 Rebecca M. Blank, U.S. Welfare Reform: What's Relevant for Europe?, July 2002

754 Ruslan Lukach and Joseph Plasmans, Measuring Knowledge Spillovers Using Patent Citations: Evidence from the Belgian Firm's Data, July 2002

755 Aaron Tornell and Frank Westermann, Boom-Bust Cycles in Middle Income Countries: Facts and Explanation, July 2002

756 Jan K. Brueckner, Internalization of Airport Congestion: A Network Analysis, July 2002

757 Lawrence M. Kahn, The Impact of Wage-Setting Institutions on the Incidence of Public Employment in the OECD: 1960-98, July 2002

758 Sijbren Cnossen, Tax Policy in the European Union, August 2002

759 Chandima Mendis, External Shocks and Banking Crises in Developing Countries: Does the Exchange Rate Regime Matter?, August 2002

760 Bruno S. Frey and Lars P. Feld, Deterrence and Morale in Taxation: An Empirical Analysis, August 2002

761 Lars Calmfors and Åsa Johansson, Nominal Wage Flexibility, Wage Indexation and Monetary Union, August 2002

762 Alexander R. W. Robson and Stergios Skaperdas, Costly Enforcement of Property Rights and the Coase Theorem, August 2002

763 Horst Raff, Preferential Trade Agreements and Tax Competition for Foreign Direct Investment, August 2002 